\title{
Chapter 4 \\ Moving Towards an ETS in Mexico: The Case of International Cooperation
}

\author{
Neydi Cruz and Mireille Meneses
}

\begin{abstract}
Mexico has participated in different international climate initiatives and has benefited from international collaboration. This cooperation, both at the political and technical levels, has been crucial for the design and implementation of the national carbon market. Through its climate diplomacy leadership, Mexico has played a key role in international carbon pricing initiatives, and in the technical sphere, the country has benefited from peer-to-peer international experiences and knowledge. This chapter analyzes those initiatives and their contribution to continue broadening collaboration towards a carbon market in the country. It explores how recent changes to the environmental agenda, adopted as of 2018 by the new federal administration, could hinder the implementation of the market mechanism.
\end{abstract}

Keywords International cooperation - Development assistance committee • Mitigation · Trade

\section{Introduction}

Since becoming a signatory to the United Nations Framework for Climate Change (UNFCCC) in 1994, Mexico has pursued the implementation of public policies to ensure sustainable development and to address environmental degradation. The exposure of the country to a climate agenda and the historic discussions around the decarbonization of the energy sector influenced the development of public policies and substantial reforms, particularly in the energy sector (Valenzuela and Studer 2016). This climate leadership has been materialized into domestic economic instruments to promote environmental protection, phase out fossil fuel subsidies and foster the use of alternative sources of energy. These policies in Mexico have sought to respond

Electronic supplementary material The online version of this chapter (https://doi.org/10.1007/978-3-030-82759-5_4) contains supplementary material, which is available to authorized users.

N. Cruz $(\bowtie) \cdot$ M. Meneses

Instituto Mora-CONACYT, Mexico City, Mexico

(C) The Author(s) 2022

S. Lucatello (ed.), Towards an Emissions Trading System in Mexico: Rationale, Design and Connections With the Global Climate Agenda, Springer Climate,

https://doi.org/10.1007/978-3-030-82759-5_4 
to an incipient need to address the climate crisis and have evolved in parallel with the international conversations led by the UNFCCC.

Climate change discussions in the country gained relevance with the foundation and entry into force of the UNFCCC and when the negotiations of the Kyoto Protocol started back in 1995. Despite not being part of the countries with an emission reduction goal within the Kyoto Protocol (Annex I countries), Mexico was one of the first UNFCCC countries to ratify it in 2000 (United Nations 2020). Climate advocacy in the country has been variable across government administrations. Four presidential terms have passed since Mexico's adhesion to the UNFCCC, but only two terms stand out for the rate of policy development and bold commitments. This could have been partly influenced by personal beliefs or to keep pace with a constantly changing international agenda (Balderas Torres et al. 2020; Valenzuela and Studer 2016). Regardless of the political divisions in its government, Mexico's climate agenda advanced steadily (Meirovich 2014) and helped position itself as a pioneer in the Latin American region.

Mexico's advocacy for a strong environmental policy, and more recently for carbon pricing, positioned the country as a regional leader. However, as the entry into force of the Paris Agreement approached, some of the political work had been done, yet much of the technical problem remained. The implementation of carbon pricing was not clear to many countries and this indicated the lack of technical capacities for ensuring effective implementation.

Several countries and institutions that backed the implementation of carbon pricing also supported the founding of larger advocacy groups for promoting capacity-building through international cooperation. Thanks to the thought leadership demonstrated in the process, Mexico attracted the attention of international partners who supported the country in building its climate policy. Over the next sections, we will present the main political milestones that take Mexico to the adoption of one of the most ambitious efforts for climate change mitigation: a national carbon market.

\section{The International and National Context of Market-Based Mechanisms}

The Paris Agreement seeks to stop the division that existed in the Kyoto era between Annex I countries and the rest of the world. The Agreement recognizes the common but differentiated responsibilities of the members and calls for a coordinated response to climate change. It also acknowledges the importance of international cooperation and support among countries in order to achieve global mitigation and adaptation goals. The Paris Agreement itself explicitly refers to international cooperation on adaptation efforts and relating to the outcome of the global stocktake. However, it can be implicitly found in the cooperative approaches envisioned as part of Article 6. 
Article 6 of the Paris Agreement promotes cooperation among countries in order to achieve their national mitigation goals. Article 6.2 refers to the use of voluntary cooperative approaches to facilitate emissions reductions that can be translated into internationally transferred mitigation outcomes (ITMOs). With this, the Paris Agreement recognizes the existence of market-based instruments as a means to catalyze climate finance, promote technology transfer and enable GHG emissions reduction. The rules on how this mechanism will work are still a work in progress, however, countries such as Canada, Japan, Switzerland and Sweden have started to negotiate bilateral agreements to test the Article ITMO transactions (Greiner et al. 2019).

Cooperative responses like these are required because most greenhouse gases accumulate over time and mix globally. Effective mitigation will not be achieved if individual agents advance their own interests independently (IPCC 2014). International cooperation can provide an enabling environment for the implementation of ambitious actions implied by limiting global warming to $1.5{ }^{\circ} \mathrm{C}$. It could then be achieved in all countries and for all people, in the context of sustainable development. International cooperation is a critical enabler for developing countries and vulnerable regions (IPCC 2018).

Over the presidential period from 2006 to 2012, climate change and environment policies were considered a priority in Mexico in terms of political leadership and budget allocation to the Ministry of Environment and Natural Resources (SEMARNAT). During this six-year period, the country enhanced its climate leadership by hosting the Conference of the Parties (COP)-16 in Mexico, pursuing the establishment of the Green Climate Fund and publishing domestic planning instruments such as the National Strategy on Climate Change (NSCC) and the Special Program of Climate Change (SPCC). Other sectoral programmes to address issues such as deforestation and forest degradation were also established. All these efforts were materialized at the end of the administration with the enactment of the General Law on Climate Change (GLCC) in 2012 (Balderas Torres et al. 2020).

This climate leadership in Mexico was sustained over the subsequent presidential period (2012-2018), however, its importance decreased during the first couple of years when other social and economic issues were under the spotlight (Balderas Torres et al. 2020). Climate change in Mexico gained traction towards the COP-21 in 2015 when countries were expected to present their national emission reduction targets and agree on a new climate change accord. This presidential term showcased five major milestones in the domestic climate agenda: the establishment of a carbon tax applicable to fossil fuels (D.O.F. 2013); the submission of the Nationally Determined Contribution (NDC) to the UN; the approval of the Energy Transition Law (ETL) (D.O.F. 2015) to promote the development of renewable energy projects and the national strategy for reforestation and forest degradation projects (CICC 2017); and the creation of a national carbon market. Towards the end of this period and after the entry into force of the Paris Agreement, the GLCC was reformed to incorporate the provisions of the Agreement and the national emission reduction pledges. Besides streamlining the principles of the Agreement, the GLCC also established a mandatory Emissions Trading System (ETS) in the country to enter into force in 2019. 
The experience of the country with market-based mechanisms as an instrument for climate change mitigation dates back to the entry into force of the Kyoto Protocol in 2005. The Protocol established flexibility mechanisms such as Joint Implementation (JI), the International Emissions Trading (IET) and the Clean Development Mechanism (CDM) to assist Annex I countries in the achievement of their emissions reduction targets. While the first two mechanisms focussed on the implementation of mitigation activities in developed countries, the CDM was the only projectbased mechanism that opened the door for mitigation activities hosted in developing countries.

Upon the entry into force of the Protocol, the CDM was perceived as an opportunity for catalyzing investment in Mexico and this interest resulted in the creation of domestic instruments to facilitate understanding of the CDM. In 2006, SEMARNAT, the National Bank for Foreign Trade (BANCOMEXT) and the World Bank Group signed a Memorandum of Understanding that formalized the cooperation for the design of the Mexican Carbon Fund known as FOMECAR. This instrument operated as a technical assistance and financing mechanism to promote CDM projects in the country. FOMECAR responded to the need for a mechanism that would combine efforts to identify, promote and develop GHG mitigation projects under the CDM. In order to finance CDM projects in Mexico, other cooperation instruments in the matter were signed with countries such as Austria, Canada, Denmark, France, Germany, Italy, Japan, the Netherlands, Spain and Portugal (INE 2006).

These agreements enabled the development of CDM projects that increased climate finance to mitigation activities in the country, mainly driven by the private sector. The energy, waste and transport sectors benefitted largely from CDM transactions. The Climate Change Committee in the Energy Sector was instituted to identify potential mitigation opportunities under the CDM in Mexico. It was coordinated by the Ministry of Energy (SENER) and led by relevant energy institutions in Mexico, such as PEMEX. This Committee identified several renewable energy projects, as well as methane emissions reductions for the hydrocarbon sector. PEMEX identified nearly 44 potential CDM projects and therefore, signed agreements with the World Bank and the Inter-American Development Bank (IDB) to expand its opportunities under future carbon markets (INE 2006). Given the large contribution of the energy sector in Mexico to national GHG emissions, it could be argued that its involvement in the CDM, particularly the case of PEMEX, was one of the main drivers that triggered the interest of Mexico in pursuing market-based mechanisms as a cost-effective option for reducing GHG emissions.

To date, approximately 192 Mexican projects are registered under the CDM, however, only 72 projects have issued Certified Emission Reductions (CERs). The interest in CDM projects decreased between 2012 and 2013 as a result of the collapse in global market prices (Harvey 2012). Consequently, many of the projects registered during that period were unable to complete the validation and verification phases or were simply withdrawn in the process. Projects registered before 2013 continued to generate CERs in subsequent crediting periods, however, the demand for CDM credits decreased as well. The GLCC (D.O.F. 2012) highlighted the importance of channelling international resources to finance GHG mitigation projects through 
public policies. Mexico tried to reactivate the interest of CDM projects by including a compensation mechanism to meet obligations under the carbon tax. The rules for this compensation mechanism were approved until 2017 and so far, companies have not used CDM credits in lieu of their obligations under the carbon tax.

The Kyoto Protocol was an international instrument pioneering in the implementation of market instruments for meeting emission reduction goals. Different countries including Mexico, private actors, international institutions, and civil society organizations around the world recognized the need to include similar market mechanisms in the new global climate order. Such actors led the creation of various initiatives and alliances that sought to influence the use of carbon prices as a key policy instrument to combat climate change. These efforts materialized in the inclusion of market-based instruments to support the achievement of the Paris Agreement goal to limit global warming to below $2^{\circ}$.

Mexico has actively participated in several international initiatives, partnerships and readiness funds which aim to support not only the development of carbon markets, but also to enhance capacity building. These initiatives assisted the country in designing its national ETS from a political and technical level.

The international public advocacy work began in 2014 at the UN Climate Summit, where 73 subnational governments, 11 local governments and more than one thousand businessmen-representing 54\% of the global GHG emissions, 52\% of the world's GDP and almost half of the world's population of that time-subscribed the first global carbon pricing statement, giving a positive signal to the private sector and the need to invest in climate solutions (World Bank 2014). Mexico, at the head of the state level, was part of this launching.

The WB led this international call not only with the federal government, but also with congressmen. In June 2014, Mexico hosted the 2nd World Summit of the Global Legislators Organization for a Balanced Environment (GLOBE) where the WB Vice President and Special Envoy for Climate Change requested that legislators engage in carbon pricing instruments and ensure their governments support the declaration to be adopted later in September of that year.

In March of 2015, Mexico was the first developing country to submit its NDC to the UNFCCC. Climate international negotiators and practitioners referred to the 'Mexican model' when an NDC included considerations of adaptation, human rights and gender. It was also relevant that Mexico explicitly conditioned its emission reduction commitment to the inclusion of "international carbon pricing, carbonsensitive levies, technical cooperation, access to low-cost financial resources and technology transfer" (México 2015) in the global agreement.

Global political support was needed for an ambitious and extensive agreement. Therefore, the French Presidency in charge of the climate talks innovated the format by organizing a segment of leaders and high-level representatives to initiate the COP21. Over 150 heads of state and government gathered the first day, being "the largest group of leaders ever to attend a UN event in a single day" (UNFCCC 2015). In that context, high-level events and declarations took place on November 30th, 2015, sending political signals of what should be covered by the climate accord. 
At that point, for example, it was not certain if parties were going to agree to include a reference of market-based instruments into the expected agreement. Then, climate diplomacy took place. The heads of state from Canada, Chile, Ethiopia, France, Germany and Mexico, as well as the Secretary General of the OECD joined the president of the $\mathrm{WB}^{1}$ in a carbon pricing panel to urge other nations and companies to put a price on carbon. For Mexico, "carbon pricing is an effective means of reducing greenhouse gas emissions and promoting the use of cleaner fuels" (Gobierno de México 2015), said then the Mexican President ${ }^{2}$ even when the country had a minimum carbon levy in place which was criticized also because the revenues were not allocated to environmental expenditure. To advise on what Mexico could proclaim, the Ministries of Environment, Finance and Foreign Affairs had to concur; before that point, there was not much joint work at the political level on this matter.

Also, during COP-21, ${ }^{3}$ the Carbon Pricing Leadership Coalition (CPLC) was launched with the aim of promoting the use of carbon pricing as a policy instrument to reduce GHG emissions. Mexico supported the CPLC as a founding member and the journey began. From that moment, Mexico started to be a key political player within carbon pricing momentum. This international exposure triggered domestic discussions on the matter. To date, representatives from the public, private sector, NGOs and universities are part of the CPLC. ${ }^{4}$

In 2016, there were three important political accomplishments for carbon pricing. First, the heads of state of Mexico and Germany reaffirmed their cooperation on climate $^{5}$ with three specific commitments on carbon pricing-one being German assistance to Mexico and alliances with other partners (Germany-BMU 2016). The Second was the declaration Setting a Transformational Vision for 2020 and beyond from the carbon pricing panel $^{6}$ calling for a carbon pricing goal to double coverage of global emissions with explicit carbon prices to $25 \%$ by 2020 and to reach $50 \%$ by 2030. It was also recognized that such a goal could be achieved by broadening and

\footnotetext{
${ }^{1}$ Note from the authors: days before the media event, high-level representatives from China and the United States were confirmed to participate.

${ }^{2}$ In addition to the official high-level segment, the president of Mexico only participated in two events while at the COP-21: the launching of Mission Innovation and the carbon pricing panel.

${ }^{3}$ In the margins of the COP-21, Mexico joined a ministerial declaration on carbon markets promoted by New Zealand, committing to "work together to ensure the development of standards and guidelines for using market mechanisms that ensure environmental integrity and avoid any doublecounting or double-claiming of emissions reduction units" (New Zealand 2018). However, this international cooperation did not occur on a bilateral basis.

${ }^{4}$ Through the work of regional working groups, the CPLC triggers the exchange of knowledge and best practices by facilitating dialogue between the public and private sectors on relevant issues, such as nature-based solutions, competitiveness, monitoring reporting and verification, among others. Mexico, as part of the Americas Working Group, has shared its experience in establishing a carbon tax and recently implementing the ETS.

${ }^{5}$ Joint Declaration between the Government of the Federal Republic of Germany and the Government of the United Mexican States on Climate Action and the Energy Transition and Biodiversity.

${ }^{6}$ This statement vision was released parallel to the signing ceremony of the Paris Agreement, which was politically relevant at the time.
} 
deepening new and existing carbon prices and that international cooperation was key in such efforts. Mexico's contribution to this statement was robust. There were clear mitigation goals based on the market mechanisms already embedded in legislation: a carbon tax, clean energy certificates and green bonds (World Bank 2016).

Third, at the North American Leaders' Summit, the heads of state of Canada, Mexico and the United States (U.S.) embraced an unprecedented statement on climate, clean energy and environment, which led to the adoption of a partnership and an action plan. This was a historical commitment to 51 specific actions to ensure a more modern, secure and cleaner future in the region. Recognizing the role that carbon markets can play in helping achieve climate targets while driving innovation and support robust implementation of the Paris Agreement, the three countries were promising to share best practices and technical solutions to improve accounting effectiveness, as well as encouraging sub-national governments to share lessons learned about the design of effective carbon pricing systems and supportive policies and measures (Whitehouse 2016).

This North American signal was a breaking point and a spotlight to the world. However, five months later a new administration in the U.S. not only withdrew support to these vows, but also denied climate change. However, Canada, Mexico and the U.S. Climate Alliance ${ }^{7}$ moved to a decentralized (national-subnational) cooperation to accelerate climate policy efforts across North America, including carbon pricing considerations. The new North American Climate Leadership Dialogue (NACLD) addressed among others, carbon pricing instruments. By September 2018, partners at the Global Climate Action Summit in San Francisco were still highly dedicated to incorporate the cost of carbon pollution into decision-making, but the 2018/19 progress update (Gobierno de México, Canada and US Climate Alliance 2019) submitted at the 2019 UN Secretary General's Climate Summit lacks an allusion to carbon pricing.

A year later, the first regional meeting ${ }^{8}$ on carbon pricing took place in early 2017 in Mexico, organized by SEMARNAT and the World Bank. Again, the Ministries of Environment, Finance and Foreign Affairs convened to send a message on the importance of carbon pricing policies (Gobierno de México-SEMARNAT 2017a, b, c). The meeting also welcomed the beginning of crucial international collaboration among private, public and social organizations. ${ }^{9}$ Later that year, Mexico hosted the Latin

\footnotetext{
${ }^{7}$ The U.S. Climate Alliance is a bipartisan coalition of then 15 U.S. Governors and now supported by 25 states.

8 "The Advantage of International Cooperation in Achieving Regional Mitigation Goals in the Americas" was held in Mexico in January 2017, bringing together participants from governments, businesses, civil society and international organizations.

9 "The spirit of international collaboration was reflected in among other actions, by the signing of a MoU between the Business Council for Sustainable Development of Mexico (CESPEDES) and the International Emissions Trading Association; as well as an MoU between the Mexican Ministry of Environment and Natural Resources, and Environmental Defense Fund.” (CPLC 2017) A keystone was for local and global business associations which jointly developed a comparison of core policy elements of existing carbon markets, including private sector views on lessons learned and best practices (IETA 2017).
} 
American Caribbean Carbon Forum combining efforts with the council meeting of the World Business Council for Sustainable Development (WBCSD) held in parallel, which included a carbon pricing position as part of its perspective on climate action and policies (WBCSD 2017).

The combination of political understanding and technical preparedness was successful for Mexico, both, within its institutions and with the international partners. Several stakeholders ${ }^{10}$ looked at Mexico as a main ally and a regional leader on carbon pricing. This variety of institutions became relevant in the implementation of the carbon market in Mexico in the following years.

\section{International Cooperation to Develop an ETS in Mexico}

With the ratification of the Paris Agreement and the establishment of national emission reduction goals, the inclusion of market-based instruments to achieve mitigation objectives was a natural consequence of climate leadership in Mexico. The GLCC of 2012 offered a glimpse of a potential carbon market in the country. Consequently, Mexico began with the deployment of actions towards the establishment of a carbon market. This process started with the entry into force of the National Registry of Emissions (RENE). The ultimate objective of this instrument was to collect information on GHG emissions from facilities that emit more than 25,000 $\mathrm{tCO}_{2} \mathrm{e}$, which included entities in sectors such as energy, transportation, industry, among others. For the implementation of RENE, various international partners supported Mexico, such as the US Agency for International Development (USAID) and the German development agency (Deutsche Gesellschaft für Internationale Zusammenarbeit, GIZ) which developed training workshops to prepare private sector companies to comply with such reporting obligations and identify opportunities for reducing its carbon footprint (GIZ 2015).

Driven by the need to achieve a collective emissions reduction goal and by the opportunity to use market-based mechanisms to that end, developed countries assigned resources to support other nations in achieving such goals. In terms of ODA committed to market and financial mechanisms for fighting climate change, Germany provides almost half of the flows for this purpose among the five donors who support Mexico on the matter. The United States, Canada, Norway and the United Kingdom are the other donors, listed in descending order of ODA amounts.

This cooperation from the Development Assistance Committee (DAC) members to Mexico was dedicated to creating the necessary institutional preconditions and technical capacities of both public and private actors for establishing and implementing an ETS, as well as supporting the Mexican decision-making processes.

\footnotetext{
${ }^{10}$ Such as the governments of California, Canada, Chile, France and Germany, as well as colleagues from the World Economic Forum (WEF), Carbon Disclosure Project (CDP), the International Emissions Trading Association (IETA), the OECD, the International Monetary Fund (IMF) and the Environmental Defense Fund (EDF).
} 
The institutions executing this cooperation are diverse: public (federal and local), private, academia, non-governmental organizations and international initiatives. Some specific collaboration (OECD 2020a, b) is to:

- Develop a national greenhouse gas emissions registry.

- Produce scientific analyses and political recommendations on sector coverage, emissions thresholds and economic impacts.

- Support ministries, companies and financial institutions through capacity building on their roles and responsibilities in the market.

- Improve Mexico's ability to manage carbon emissions by introducing carbon credits from different standards that will be transacted in public auctions.

- Support Mexico's participation in the Forest Carbon Partnership Facility's Readiness Fund.

- Establish international dialogues and exchanges with jurisdictions that dispose of an ETS.

- Disseminate lessons learned in the Mexican context.

- Enhance measurement, reporting and verification with the Pacific Alliance.

- Coordinate internationally on emissions-related policy initiatives.

German cooperation has been the major technical ally in setting the stage for the ETS in Mexico. The German Federal Ministry for the Environment (BMU) commissioned GIZ to work together with SEMARNAT in improving decision-making capacities for the design of the national ETS. This was implemented under the project called "Preparation of an Emissions Trading System in Mexico", known as SiCEM, which has been extended until 2023 (IKI n.d.). ${ }^{11}$ By holding technical workshops and study tours for those responsible for ETS implementation, SiCEM has contributed to increasing preparedness in the country. This benefited not only government officials, but also companies. SiCEM seeks to promote dialogue between market actors and to strengthen technical capacities by improving understanding of the roles and responsibilities of market participants.

According to statistics from the Organization of Economic and Cooperation Development (OECD), from 2010 to 2018, Mexico received a total commitment of USD \$4.64718 billion, constant prices, 2017 (OECD 2020a, b) of bilateral aid — both, grants and loans - from DAC members, for activities targeting global environmental objectives-known as Rio Markers (see Annex 1). Around 50\% of that bilateral aid was for climate change mitigation. (See Table 4.1.)

Although this USD $\$ 4.6$ billion represented barely $2 \%$ of the total bilateral aid to all developing countries on the same issues and time, during these nine years, 14 developed countries committed to support Mexico with 265 climate projects for mitigation and 96 projects for adaptation.

Just to have an idea of the increased international support for environmental purposes, during the eight previous years (2002-2009) DAC donors committed to Mexico only $6 \%$ of what they committed the following nine years. (See Fig. 4.1.)

\footnotetext{
${ }^{11}$ IKI (n.d) SiCEM-Preparación de un Sistema de Comercio de Emisiones en México. Retrieved from http://iki-alliance.mx/portafolio/preparation-of-an-emissions-trading-system-ets-in-mexico/.
} 
Table 4.1 Bilateral ODA commitment to Mexico from DAC members

\begin{tabular}{|c|c|c|c|c|}
\hline \multicolumn{4}{|c|}{$\begin{array}{l}\text { For Rio Markers (biodiversity, climate change and } \\
\text { desertification) } \\
\text { USD millions, constant prices, } 2017\end{array}$} & For all sectors and purposes \\
\hline \multirow[t]{2}{*}{ Years } & 2002-2009 & $\$ 285.48$ & & $\$ 2,656.49$ \\
\hline & 2010-2018 & $\$ 4,647.18$ & & $\$ 6,927.36$ \\
\hline \multirow{6}{*}{$\begin{array}{l}\text { Rio Markers } \\
(2010-2018)\end{array}$} & Biodiversity & $\$ 488.42$ & $11 \%$ & \\
\hline & $\begin{array}{l}\text { Climate change } \\
\text { mitigation }\end{array}$ & $\$ 2,344.72$ & $50 \%$ & \\
\hline & $\begin{array}{l}\text { Climate change } \\
\text { adaptation }\end{array}$ & $\$ 276.19$ & $6 \%$ & \\
\hline & Desertification & $\$ 0.75$ & $0 \%$ & \\
\hline & Environment & $\$ 1,537.09$ & $33 \%$ & \\
\hline & Total & $\$ 4,647.18$ & & \\
\hline
\end{tabular}

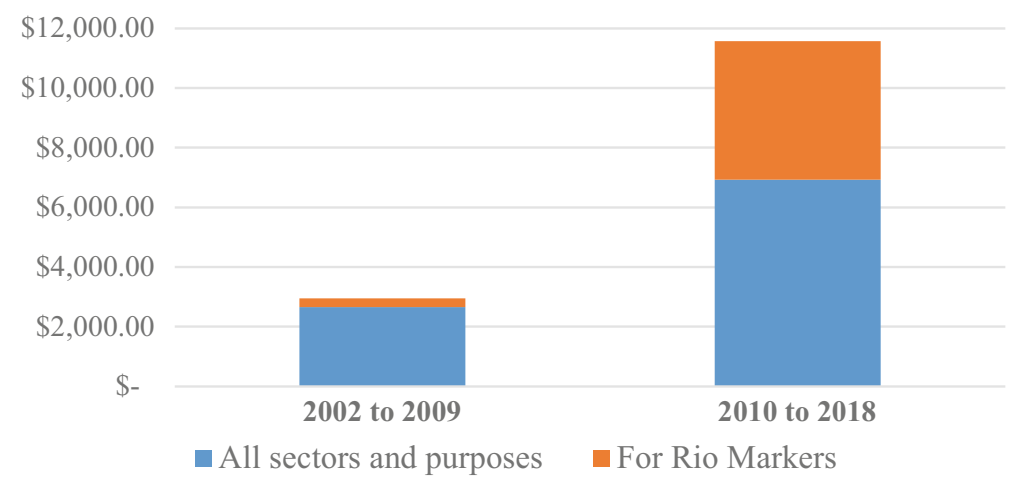

Fig. 4.1 Bilateral ODA commitment to Mexico from DAC members

In regards to multilateral support, in 2007, the Mexican government acquired the first debt (loan accountable as official development assistance, ODA) to achieve climate goals. In 2010, Mexico established debt instruments with the Inter-American Development Bank (IADB) for climate purposes. Since then, Mexico has taken part in climate investment funds (CIF), projects with the International Finance Corporation (IFC), the Global Environment Facility (GEF), the World Bank (WB), the International Fund for Agricultural Development (IFAD) and the European Development Bank (EIB); listed in order of length of the partnership.

The debt instruments have evolved from bilateral to multilateral commitments. According to the OECD Climate-related development finance data visualization portal, in 2017, $71 \%$ of the support to Mexico comes from multilateral institutions-mainly the IADB, and only $29 \%$ is bilateral-including some grants (OECD 2020a, b). 
With the information available in the OECD database, as well as official reports from Mexico and its international partners, we can identify the main environmental topics where Mexico has received international cooperation and highlight those related to climate mitigation (see Annex 1), so as to finally focus on the alliances to develop the Mexican ETS.

It is important to highlight that a third of bilateral and multilateral mitigation aid is for energy-related projects (promotion of energy efficiency and renewable energies, generation of electrical energy and support to the energy transition in the country, especially energy auctions). Hence, confirming that the majority of the cooperation received is earmarked for mitigation projects.

According to the Gupta et al. (2014), investment in CDM activities around the world amounted to over USD \$ 400 billion between 2004 and 2012. Investment in the energy sector is estimated at almost USD\$25 billion in 2011. Moreover, 100 carbon funds were created to finance carbon projects. These reported a capital of nearly USD\$ 14.2 billion, of which $48 \%$ corresponds to private capital, $29 \%$ to government funding and $23 \%$ to hybrid sources (public and private). Nevertheless, the amount of private resources provided to developing countries remains unknown (IPCC 2014).

Besides leveraging the political advocacy for carbon pricing instruments, the financial and technical support provided by the World Bank has been instrumental in the development of carbon pricing policies in Mexico. The Partnership for Market Readiness (PMR) is an initiative managed by the World Bank to assist developing countries in the preparation and implementation of policies to mitigate climate change. It is mainly focussed on carbon pricing instruments. Countries forming part of this initiative benefit from grant funding to develop market-based instruments for GHG emission reduction and to facilitate NDC implementation. The PMR also builds a knowledge-sharing platform that allows countries to exchange lessons learned and best practices to trigger collective and innovative climate action.

Since 2012, the PMR has been supporting Mexico in the implementation of Nationally Appropriate Mitigation Actions (NAMAs) across different sectors (i.e. transport and housing) and recently, became a cornerstone for the design and establishment of the ETS in the country. The initial PMR working programme approved for Mexico was adapted upon the country's request to reflect the need for developing a national carbon market (PMR 2018).

In October 2017, SEMARNAT, together with the Mexican Stock Exchange and MexiCO2 announced the launching of a carbon market simulation exercise. This exercise was implemented online over ten months and was carried out with the support of the World Bank through the PMR (SEMARNAT 2018). More than 90 private sector representatives took part, seeking to enhance their capacities and improve understanding of the dynamics of a compliance carbon market. This simulation was the beginning of a series of technical workshops designed for non-state actors ahead of the entry into force of the mandatory carbon market in Mexico.

The World Bank and GIZ enabled the dialogue between the private and public sectors and fostered capacity-building through technical studies and workshops. The knowledge acquired by government officials will be reflected in the development of policy and regulatory instruments for the formal establishment of the ETS. 
The support received was instrumental for the alignment of the regulatory framework and policy instruments with the emission reduction commitments assumed internationally.

\section{Mexico's Regional Pivotal Role}

Representatives of Colombia, Chile, Mexico and Peru from the Working Group on Environment and Green Growth of the Pacific Alliance identified a major gap among these countries for the implementation of market-based policies. The Pacific Alliance countries determined that monitoring, reporting and verification (MRV) systems for emissions accounting was an area for further improvement and was, therefore, included in the Cali Declaration of 2017 (Alianza del Pacífico 2017).

Pacific Alliance countries are committed to collaborating on an analysis of the scope of MRV systems in the region. Although this statement did not explicitly reference market mechanisms for driving GHG emissions reductions, it attracted the attention of other countries willing to support such an endeavour and was used as an indication of the regional interest in pursuing carbon pricing. Thus, Chile, Colombia and Mexico, supported by other national and sub-national governments in the Americas, as well as international institutions, adopted the Declaration on Carbon Pricing in the Americas (IETA 2018; Cruz et al. 2018). As part of this declaration, national and subnational country members established a platform for cooperating to improve technical capacities for the design and implementation of carbon prices, to explore synergies between public and private actors and to set comparable MRV criteria, among others. A decisive component during the negotiation was to ensure financial mechanisms to support this platform. From the beginning, the two main donors to the initiative were the World Bank through the PMR, and the UN Economic Commission for Latin America and the Caribbean (ECLAC), with the funding support of the European Union, via EUROCLIMA. SEMARNAT was a key facilitator, especially in terms of inclusion and follow up with ECLAC and EUROCLIMA.

The strong collaboration with the government of California to develop and implement carbon pricing systems and other market-based instruments deserves special mention. Work initiated in $2014^{12}$ towards the development of, inter alia, rigorous monitoring, reporting and verification to support carbon pricing or regulatory mechanisms, including potential linkage of both carbon markets (CalEPA 2018). It showed early impacts due to the financial resources available and specialized advisors based in Mexico.

California and Quebec were among the first cap and trade mechanisms to become fully linked. SEMARNAT and Quebec also agreed to collaborate, ${ }^{13}$ but it was never

\footnotetext{
12 In 2014, a Memorandum of Understanding to enhance cooperation on Climate Change and the Environment was signed between the State of California and SEMARNAT and Mexico's National Forestry Commission.

${ }^{13}$ A Memorandum of Understanding was signed in October 2015 with the purpose of promoting and carrying out cooperative activities related to environmental issues including, inter alia, climate
} 
operationalized. Another less successful effort was working with Ontario, also on carbon pricing, ${ }^{14}$ but it never went beyond meetings. The political partnership, especially with both California and Quebec, continued through the CPLC and the NACLD.

Political agreements are not the only source of cooperation. In recent years, SEMARNAT has participated in the negotiation of environment or sustainable development chapters within trade agreements. A new chapter on the environment was incorporated in the modernization of the North American Free Trade Agreement that derived in the recent United States-Mexico-Canada [Free Trade] Agreement (USMCA), and a new parallel Agreement on Environmental Cooperation (AEC) was adopted. Although it was impossible to mention climate change due to the US position on the matter, there are climate-related areas of cooperation including market mechanisms and other flexible and voluntary mechanisms under the "supporting green growth and sustainable development" part of the AEC Work Program (US-EPA 2018). What is remarkable about this allusion to trilateral cooperation is the long-term opportunity to develop technical cooperation, develop studies, compare MRV systems and other carbon market issues, among Mexico's most important economic partners.

At the same time, the trade portion of the new European Union-Mexico Global Agreement considers the joint work in preparing and adopting carbon pricing actions including emission trading systems (European Commission 2018). See Annex 2 for Mexico's international advocacy for carbon pricing and international cooperation for the ETS.

\section{Moving Towards Implementation}

According to the rules for the trial phase of the ETS, SEMARNAT must define the market compensation scheme and must decide on the national or international protocols to allow for offsetting emissions within the national ETS. The PMR is also supporting Mexico in the development of a registry for emission reductions generated as part of the ETS and the development of such compensation protocols (PMR 2018). There is no public information on when it will happen, however, these should be ready by the end of 2022 during the transition phase of the ETS towards its formal implementation.

It should be noted that since 2013, Mexico has had a voluntary carbon credit market in which various companies have participated in order to offset their emissions on a voluntary basis (CAR 2015). However, it was not until the reform of the GLCC that

change and emissions trading, according to their respective competencies, budgetary availability, and based on principles of equality, reciprocity, information exchange and mutual benefit (QuebecMRIF 2015).

14 Joint declaration between Mexico, Ontario and Quebec, committing to working together to fight climate change and seeking progress on the common commitment to pricing carbon (Gobierno de México 2016) (Ontario 2016). 
the mandatory carbon market emerged with specific emission reduction obligations. According to the GLCC reform, the market was to be implemented gradually in two phases: a pilot phase starting in 2019 and a formal phase, starting in 2022. Due to delays in the approval of the rules of operation of the pilot phase, the entry into force did not begin until January 2020. Consequently, the operation of the formal phase of the market was deferred to 2023 (D.O.F 2019).

The Partnership for Market Implementation (PMI), another initiative hosted by the WBG, will be the successor of the PMR. The PMI will assist participant countries in the implementation of domestic carbon pricing instruments and other related activities such as capacity development for the creation of institutional structures, enhancing GHG data collection and MRV frameworks, as well as NDC alignment (World Bank 2020a, b). The partnership between Mexico and the PMR concludes in July 2020. However, it has not been disclosed if Mexico will become one of the 30 jurisdictions to benefit from this initiative. Nevertheless, it is natural for the country to pursue opportunities under the PMI as a continuation of previous efforts with the PMR.

\section{Conclusion}

Over the last decade, Mexico has contributed to forging current climate governance. Due to its legislative advances, increased ambition, concrete climate actions and opportunities for investment, Mexico attracted attention from various partners. This international spotlight was a long-term consequence of a demanding civil society, a vigilant private sector, an interested congress, and of course, committed officials. Note that this document did not cover other environmental subjects related to climate, such as forests, oceans, biodiversity, education, green growth, air quality and climate pollutants, etc. in which Mexico also showed leadership. Taken altogether, these actions have made for a robust scenario.

Especially around the adoption of the Paris Agreement, Mexico was part of many climate initiatives, meetings, declarations and working groups. High-level declarations set the political, and sometimes legal framework, to land international supporteither financial or technical. Top down signals mean mandates and opportunities for implementation.

International cooperation in Mexico largely determined the pace at which the national ETS evolved. Mexico's climate leadership and the political advocacy it showed in the international arena sent strong signals that attracted the attention of international donors. In less than three years of placing carbon pricing at any possible international pact, and participating at the most strategic and highest boards, Mexico gained visibility, trust and created opportunities.

Thanks to this international support, mainly from Germany and the World Bank, it was possible to develop key regulatory instruments that would have not happened 
in the short term. This also helped to prepare the country for participation in international carbon markets. The development of national capacities for the implementation of the ETS in Mexico continues, thanks to the support of international partners. However, it must be kept in mind that there are still questions pending regarding the implementation of a future global carbon market within the Paris Agreement.

The resources-monetary or in-kind-from international partners, made it possible to complete one of the most ambitious environmental policy projects in Mexico during a time of significant budget cuts. Furthermore, the strengthening of capacities and knowledge transfer was promoted beyond the public sector and reached the private sector and civil society. Thanks to such support, non-state actors are now in a better position to assume their roles and facilitate compliance with national climate policies.

Some of the bilateral agreements signed with other international partners resulted only in a press release without ever being implemented. This could be attributed to many factors, such as a sudden change in national priorities, politics or the lack of enough specialized human resources by the Mexican counterpart. However, these helped to build momentum and led to other initiatives that were effectively materialized in action plans.

Throughout this process, the Ministries of Environment, Finance and Foreign Affairs benefited not only from the transfer of knowledge promoted by its international partners, but also from the support of external experts who collaborated on projects led by the World Bank and GIZ. International cooperation is deemed effective when this transfer of knowledge satisfies specific needs of the country and remains beyond a specific project. In the case of Mexico, the technical capabilities developed as a result of international support will only thrive if there is political willingness to maintain the policy and regulatory instruments that enabled such capacity building to take place. The knowledge acquired will also persist conditioned to satisfying primary needs of the country. If there is a substantial change in the national goals, there is a risk that the capacities generated will remain stranded, leaving regulatory instruments in disuse.

Mexico's experience through diverse international initiatives advocating for carbon pricing served as a benchmark for other countries in the Latin American and Caribbean region, such as Chile, Colombia, Costa Rica and Peru. The participation of the region in these technical and political initiatives in parallel to the discussions under Article 6 of the Paris Agreement, triggered interest on the part of these countries for enhancing their preparedness for the imminent entry into force of a potential global carbon market.

Unfortunately, the new administration that took place in late 2018 adopted a different environmental agenda. This administration is focussing on a new oil refinery, has cancelled renewable energy auctions, has significantly reduced the budget for the environment - and for international offices across all Ministries_-, and has restricted international participation of government officials and high-level representatives. In less than six months of running the office, the new government sent completely opposite signals on climate action. Data is not yet available to estimate how this affects the flows of ODA and multilateral support. However, there is no doubt that the 
country is facing a slowdown when it comes to achieving the international climate agenda.

This is relevant to the implementation of the ETS as the mechanism already went through an initial delay. The full establishment of the ETS is planned to be completed in 2023, one year before the termination of the current presidential term. In 2025 , countries should present the second update of their NDCs. The adequate and sustained implementation of the ETS in Mexico could allow the country to increase its climate ambition and hence, mitigation commitments. The ETS in Mexico could be a turning point in the country's climate agenda and, if used wisely, international cooperation can help accelerate the achievement of national mitigation and adaptation goals.

The climate change agenda in Mexico is uncertain. Given the lack of interest and mixed political signals that have characterized the first couple of years of the current administration, we foresee three possible scenarios for international cooperation in the country. In the first scenario, international cooperation continues but focuses on strengthening the capacities of non-state actors. This is particularly relevant for the ETS, as the private sector could be the one advocating for full implementation of the national carbon market if concrete business opportunities are identified.

In a second scenario, international stakeholders could demand that Mexico's federal government meet previous commitments. However, an excess of international pressure could have secondary effects on a government with a weak agenda and low human resources. As previously mentioned, there were some bilateral agreements that the Mexican government was unable to materialize.

In a final scenario, the climate agenda in Mexico is delayed, including the implementation of the ETS. The lack of certainty, rules and institutional infrastructure for the implementation of the ETS could put the initial efforts of the private sector and international partners in developing mitigation activities at stake, therefore, hindering climate finance opportunities for the country. There is no doubt that international alliances have been key to the carbon market in Mexico. However, it is important to bear in mind that even if the ETS is successful, any carbon market and non-market mechanism is a transitory process to a decarbonized world.

Annex 1. International Climate Cooperation for Mexico, 2010-2018 
4 Moving Towards an ETS in Mexico: The Case ...

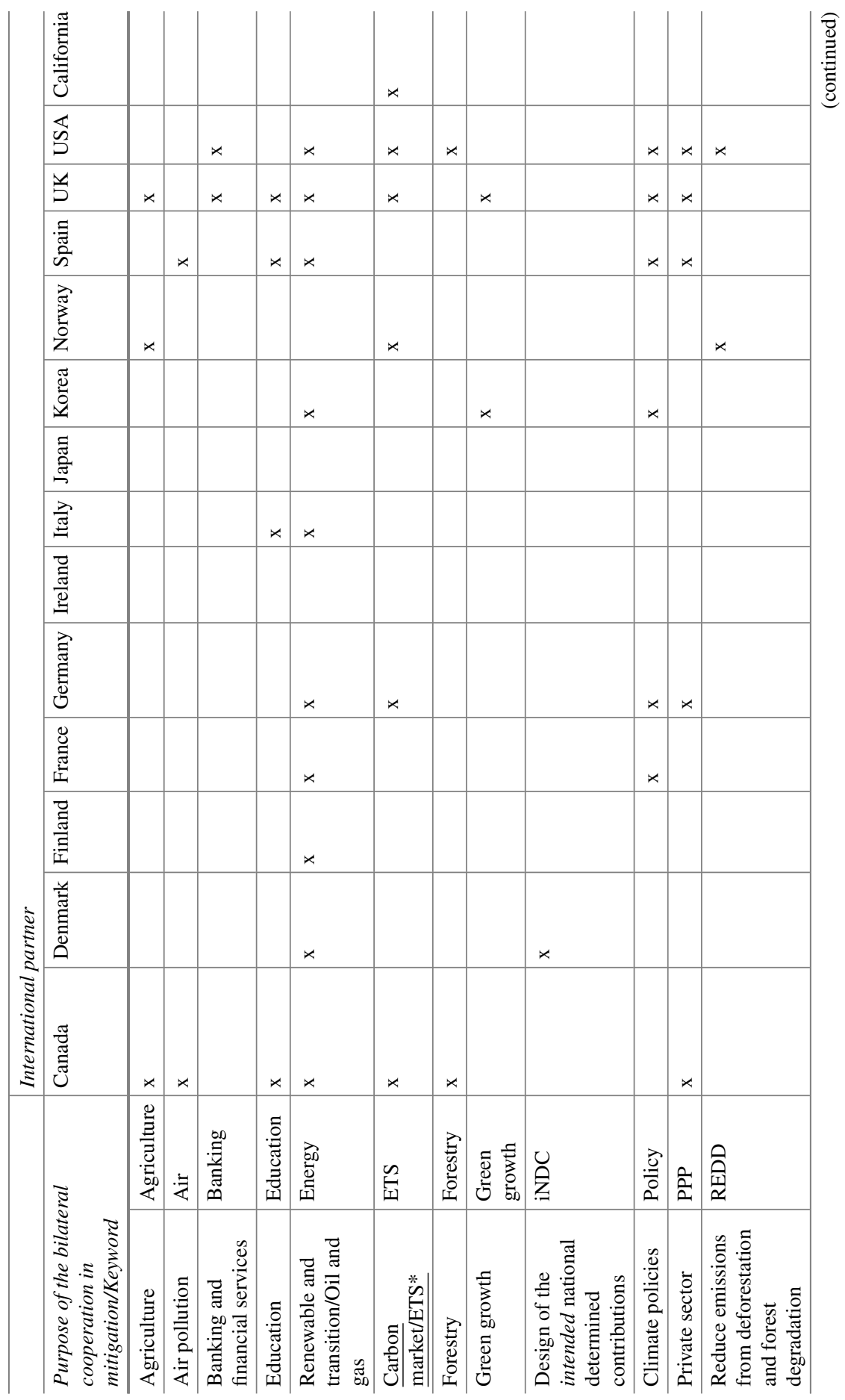




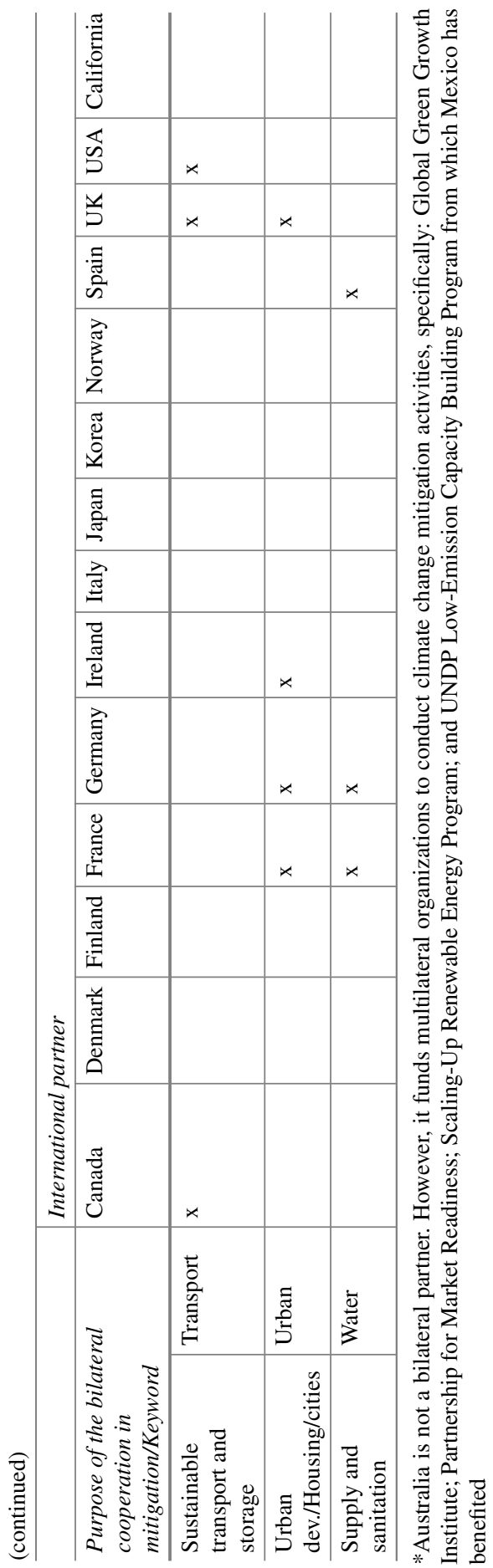


Annex 2. Mexico's international advocacy for carbon pricing and international cooperation for the ETS

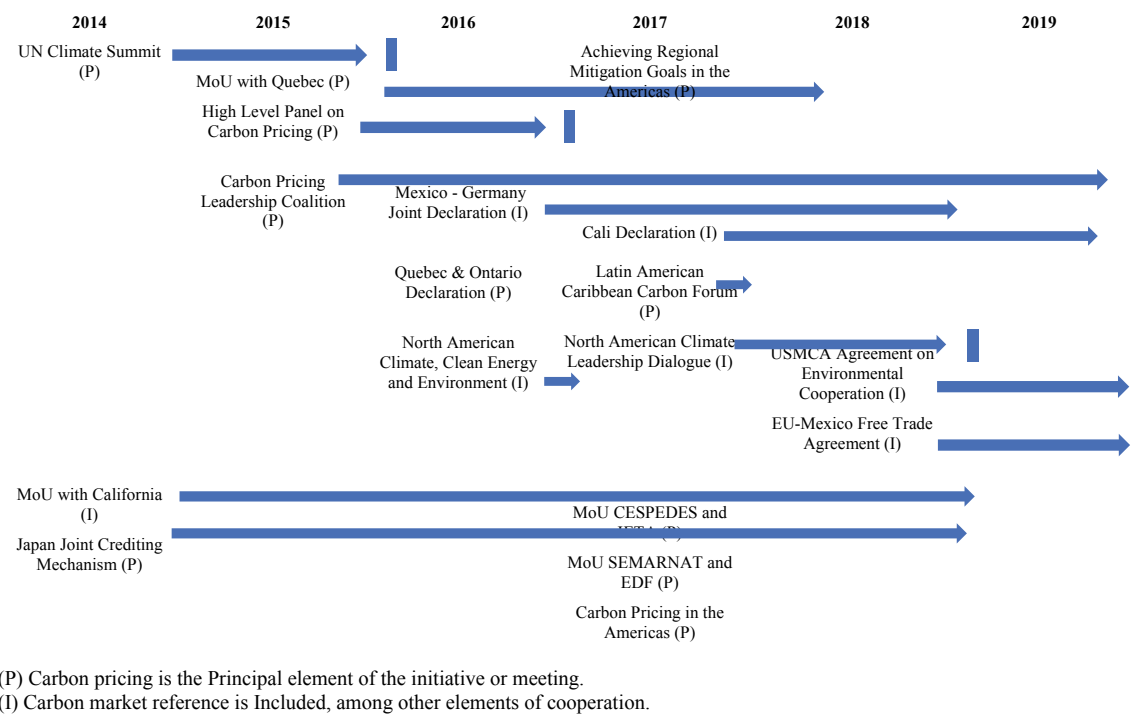

\section{References}

Alianza del Pacífico (2017) Declaración de Cali. https://alianzapacifico.net/

Balderas Torres AB, Vargas PL, Paavola J (2020) The systemic and governmental agendas in presidential attention to climate change in Mexico 1994-2018. Nat Commun 11(1):1-11. https:// doi.org/10.1038/s41467-019-14048-7

BMU (Federal Ministry for Environment, Nature Conservation and Nuclear Safety, Germany) (2016) Report Amerikas. German-Mexican Climate Action Declaration. 12 April 2016. https:// www.bmu.de/en/report/german-mexican-climate-action-declaration/

CALEPA (California Environmental Protection Agency) and Ministry of Environment and Natural Resources of Mexico (2018) California-Mexico Memorandum of understanding on climate change \& the environment 2014-2018 summary report. https://calepa.ca.gov/wp-content/upl oads/sites/6/2019/03/California-Mexico_MOU_Summary_Report_2014-2018.pdf

CAR (Climate Action Reserve) (2015) Introduction to carbon markets in Mexico. Climate Action Reserve. https://www.climateactionreserve.org/wp-content/uploads/2015/12/ClimateAction-Reserve_Mexico-Carbon-Markets-Memo-ENGLISH.pdf

CICC (Comisión Intersecretarial de Cambio Climático) (2017) Estrategia Nacional REDD+ 20172030. Repositorio Digital Especializado. México. http://www.monitoreoforestal.gob.mx/reposi toriodigital/items/show/546.

CPLC (Carbon Pricing Leadership Coalition) (2017) Blog. The advantage of International Cooperation in achieving regional mitigation goals in the Americas. January 26, 2017. https://www.carbonpricingleadership.org/blogs/2017/1/25/the-advantage-of-internati onal-cooperation-in-achieving-regional-mitigation-goals-in-the-americas 
Cruz N, Churie-Kallhauge A, Forrister D, Keohane N (2018) Declaration on carbon pricing in the Americas: building momentum among continents. IETA Insights: Greenhouse Gas Market Report. No. 3. https://www.ieta.org/2018-IETA-Insights-No-3/

DOF (Diario Oficial de la Federación) (2012) Decreto por el que se expide la Ley General de Cambio Climático, SEMARNAT, Diario Oficial de la Federación, 6 June 2012, México

DOF (Diario Oficial de la Federación) (2013) Decreto por el que se reforman, adicionan y derogan diversas disposiciones de la Ley del Impuesto al Valor Agregado; de la Ley del Impuesto Especial sobre Producción y Servicios; de la Ley Federal de Derechos, se expide la Ley del Impuesto sobre la Renta, y se abrogan la Ley del Impuesto Empresarial a Tasa Única, y la Ley del Impuesto a los Depósitos en Efectivo (Continúa en la Tercera Sección). Diario Oficial de la Federación. 11 de Diciembre de 2013. México, D.F.

DOF (Diario Oficial de la Federación) (2015) Ley de Transición Energética. Diario Oficial de la Federación. 24 de diciembre de 2015. México

DOF (Diario Oficial de la Federación) (2019) Acuerdo por el que se establecen las bases preliminares del Programa de Prueba del Sistema de Comercio de Emisiones. Diario Oficial de la Federación. 1 de octubre de 2019. México

European Commission. Trade. News archive. New EU-Mexico agreement: the agreement in principle and its texts. Brussels, 26 April 2018 — updated in May 2020. https://trade.ec.europa.eu/doc lib/press/index.cfm?id=1833

GIZ (Deutsche Gesellschaft für Internationale Zusammenarbeit) (2015) Integrated solutions that work. Integrated company report. https://www.giz.de/en/downloads/giz2015-en-Integrated-Com pany-Report.pdf

Gobierno de México (2015) Presidencia. Prensa. Participación del Presidente de los Estados Unidos Mexicanos, Enrique Peña Nieto, durante la presentación de la Iniciativa Carbon Pricing. 1 December 2015. http://www.gob.mx/presidencia/prensa/participacion-del-presidente-de-losestados-unidos-mexicanos-enrique-pena-nieto-durante-la-presentacion-de-la-iniciativa-carbonpricing

Gobierno de México (2016) Secretaría del Medio Ambiente y Recursos Naturales (SEMARNAT). Prensa. Pacchiano Alamán refrenda compromiso de México en II Cumbre de Cambio Climático de las Américas. 31 de agosto de 2016. https://www.gob.mx/semarnat/prensa/pacchiano-alamanrefrenda-compromiso-de-mexico-en-ii-cumbre-de-cambio-climatico-de-las-americas?idiom= es-MX

Gobierno de México (2017a) Secretaría del Medio Ambiente y Recursos Naturales (SEMARNAT). Prensa. Inicia foro internacional para fijar precio al carbono. 25 January 2017. https://www.gob. $\mathrm{mx} /$ semarnat/prensa/inicia-foro-internacional-para-fijar-precio-al-carbono?idiom=es

Gobierno de México (2017b) Secretaría del Medio Ambiente y Recursos Naturales (SEMARNAT). Prensa. SEMARNAT y Gobierno de Quebec firman acuerdo para fortalecer cooperación en cambio climático. 12 de octubre de 2015. https://www.gob.mx/semarnat/prensa/semarnat-y-gob ierno-de-quebec-firman-acuerdo-para-fortalecer-cooperacion-en-cambio-climatico

Gobierno de México (2017c) Secretaría del Medio Ambiente y Recursos Naturales (SEMARNAT). Blog. Acciones de México para establecer un mercado de carbono. 12 December 2017. https://www.gob.mx/semarnat/articulos/acciones-de-mexico-para-establecer-un-mercadode-carbono?idiom=es

Gobierno de México. Canada. United States Climate Alliance (2019) North American climate leadership dialogue update on progress 2018/19. December 2019. http://www.usclimatealliance. org/international-cooperation\#: :text=Canada\%2C\%20Mexico\%20and\%20the\%20U.S.,pol icy $\% 20$ efforts\%20across\%20North\%20America

Greiner S, Chagas T, Krämer N, Michaelowa A, Brescia D, Hoch S, Climate Focus CF (2019) Moving towards next generation carbon markets: observations from Article 6 pilots. https://www.climatefocus.com/sites/default/files/Moving-toward-next-generation-car bon-markets_update-june-2019-1.pdf 
Gupta S, Tirpak DA, Burger N, Gupta J, Höhne N, Boncheva AI, Kanoan GM, Kolstad C, Kruger JA, Michaelowa A, Murase S, Pershing J, Saijo T, Sari A (2007) Policies, instruments and cooperative arrangements. In: Metz B, Davidson OR, Bosch PR, Dave R, Meyer LA (eds) Climate change 2007: mitigation. Contribution of Working Group III to the Fourth Assessment Report of the Intergovernmental Panel on Climate Change. Cambridge University Press, Cambridge, United Kingdom and New York, NY, USA, pp 13-12

Gupta S, Harnisch J, Barua DC, Chingambo L, Frankel P, Garrido Vázquez RJ, Gómez-Echeverri L, Haites E, Huang Y, Kopp R, Lefèvre B, Machado-Filho H, Massetti E (2014) Cross-cutting investment and finance issues. In: Edenhofer O, Pichs-Madruga R, Sokona Y, Farahani E, Kadner S, Seyboth K, Adler A, Baum I, Brunner S, Eickemeier P, Kriemann B, Savolainen J, Schlömer S, von Stechow C, Zwickel T, Minx JC (eds) Climate change 2014: mitigation of climate change. Contribution of Working Group III to the Fifth Assessment Report of the Inter-governmental Panel on Climate Change. Cambridge University Press, Cambridge, United Kingdom and New York, NY, USA

Harvey F (2012) Global carbon trading system has 'essentially collapsed.,' The Guardian 10

ICAP (International Carbon Action Partnership) (2017) Emissions trading worldwide: status report 2017. ICAP, Berlin. https://icapcarbonaction.com/en/?option=com_attach\&task=dow nload\&id $=447$

IETA (International Emissions Trading Association) (2017) News. Press releases. IETA and CESPEDES sign MOU on Mexican Carbon Market Development and Cooperation. Mexico City, 25 January. https://www.ieta.org/page-18192/4568654

IETA (International Emissions Trading Association) (2018) IETA Insights: Greenhouse Gas Market Report. No. 3. https://www.ieta.org/2018-IETA-Insights-No-3/

IKI (International Climate Initiative) (n.d) SiCEM-Preparación de un Sistema de Comercio de Emisiones en México. http://iki-alliance.mx/portafolio/preparation-of-an-emissions-trading-sys tem-ets-in-mexico/

INE (Instituto Nacional de Ecología) (2006) México tercera comunicación nacional ante la Convención Marco de las Naciones Unidas sobre el cambio climático. México

IPCC (Intergovernmental Panel on Climate Change) (2014) Approved summary for policymakers. IPCC Fifth Assessment Synthesis Report. 1 November 2014

IPCC (Intergovernmental Panel on Climate Change) (2018) Summary for policymakers. In: MassonDelmotte V, Zhai P, Pörtner H-O, Roberts D, Skea J, Shukla PR, Pirani A, Moufouma-Okia W, Péan C, Pidcock R, Connors S, Matthews JBR, Chen Y, Zhou X, Gomis MI, Lonnoy E, Maycock $\mathrm{T}$, Tignor M, Waterfield T (eds) Global warming of $1.5^{\circ} \mathrm{C}$. An IPCC Special Report on the impacts of global warming of $1.5^{\circ} \mathrm{C}$ above pre-industrial levels and related global greenhouse gas emission pathways, in the context of strengthening the global response to the threat of climate change, sustainable development, and efforts to eradicate poverty. In Press

Japan. Ministry of the Environment. Joint Crediting Mechanism (JCM) (n.d.) Information on JCM partner countries. Mexico. July 25th, 2014. https://www.carbon-markets.go.jp/eng/jcm/ini tiatives/mexico.html

Meirovich HG (2014) The politics of climate in developing countries: the case of Mexico. Doctoral dissertation, Georgetown University

México. Gobierno de la República (2015) Intended nationally determined contribution. March 30, 2015

New Zealand. Ministry for the Environment (2018) Ministerial declaration on carbon markets. 19 April 2018. https://www.mfe.govt.nz/climate-change/why-climate-change-matters/global-res ponse/new-zealand-and-international-carbon

OECD (Organization of Economic and Cooperation Development) (2020a) Climate-related development finance data visualisation portal. https://public.tableau.com/views/Climate-relatedde velopmentfinance-RP/CRDF-Recipient?:embed=y\&:display_count=no\&\%3AshowVizHome= no\%20\#3. Accessed 1 June 2020

OECD (Organization of Economic and Cooperation Development) (2020b) Dataset: aid activities targeting global environmental objectives. https://stats.oecd.org/. Accessed 16 May 2020 
Ontario. Office of the Premier (2016) Newsroom. Ontario Working with Québec and Mexico to Advance Carbon Markets. 31 August 2016. https://news.ontario.ca/opo/en/2016/08/ontario-wor king-with-quebec-and-mexico-to-advance-carbon-markets.html

Paris Agreement, Paris, 12 December 2015, United Nations Treaty Series, No. 54113. https://tre aties.un.org/Pages/showDetails.aspx?objid=0800000280458f37\&clang=_en

PMR (Partnership for Market Readiness) (2018) Mexico PMR Project implementation status report (ISR). https://www.thepmr.org/country/mexico-0

Quebec. MRIF (ministère des Relations internationales et de la Francophonie) (2015) Partenariats. http://www.mrif.gouv.qc.ca/content/documents/fr/ententes/2015-12.pdf

SEMARNAT (Secretaría de Medio Ambiente y Recursos Naturales) (2018) Sexta Comunicación Nacional y Segundo Informe Bienal de Actualización ante la Convención Marco de las Naciones Unidas sobre Cambio Climático. México. http://cambioclimatico.gob.mx:8080/xmlui/handle/ publicaciones $/ 117$

The Whitehouse. Office of the Press Secretary (2016) North American climate, clean energy, and environment partnership action plan. June 29, 2016. https://obamawhitehouse.archives.gov/thepress-office/2016/06/29/north-american-climate-clean-energy-and-environment-partnershipaction

UNFCCC (United Nations Climate Change). News. Leaders and high-level segment. December 2015. https://unfccc.int/news/cop-21cmp-11-information-hub-leaders-and-high-level-segment

UNFCCC (United Nations Climate Change) Process and Meetings (2020) The Paris Agreement. https://unfccc.int/process-and-meetings\#:a0659cbd-3b30-4c05-a4f9-268f16e5dd6b

United Nations-General Assembly resolution 70/1 Transforming our world: the 2030 agenda for sustainable development, A/RES/70/1 (21 October 2015)

United Nations (2020) United Nations treaty collection. UN

United Nations Climate Change (UNFCCC) News. Leaders and high-level segment. December 2015. https://unfccc.int/news/cop-21cmp-11-information-hub-leaders-and-high-level-segment

United States Environmental Protection Agency (2018) 2018 Agreement on Environmental Cooperation among the Governments of the United States of America, the United Mexican States, and Canada. https://www.epa.gov/international-cooperation/2018-agreement-environmental-coo peration-among-governments-united-states

U.S. Climate Alliance (2018) Publications. Joint Statement on North American Climate Leadership. 13 September 2018. https://www.usclimatealliance.org/publications/2018/9/26/joint-sta tement-on-north-american-climate-leadership

Valenzuela JM, Studer I (2016) Climate change policy and power sector reform in Mexico under the golden age of gas. Polit Econ Clean Energy Transit 410

WBCSD (World Business Council for Sustainable Development) (2017) WBCSD Council meeting in Mexico. Business perspective on climate action \& policies. 18 October 2017. https://www. cbcsd.cz/wp-content/uploads/2017/11/Climate-action-policies-for-CM.pdf

World Bank (2014) Press release. 73 countries and more than 1,000 companies and investors support a price on carbon. September 22, 2014. https://www.worldbank.org/en/news/press-rel ease/2014/09/22/73-countries-1000-companies-investors-support-price-carbon?wptouch_prev iew_theme=enabled

World Bank (2016) Speeches \& transcripts. Carbon pricing panel—setting a transformational vision for 2020 and beyond. April 21, 2016. https://www.worldbank.org/en/news/speech/2016/04/21/ carbon-pricing-panel---setting-a-transformational-vision-for-2020-and-beyond

World Bank (2020a) State and trends of carbon pricing 2020, May. World Bank, Washington, DC. https://openknowledge.worldbank.org/bitstream/handle/10986/33809/978146481 5867.pdf? sequence $=4 \&$ is Allowed $=\mathrm{y}$

World Bank (2020b) Partnership for market implementation. [online]. https://www.worldbank.org/ en/topic/climatechange/brief/partnership-for-market-implementation 
Open Access This chapter is licensed under the terms of the Creative Commons Attribution 4.0 International License (http://creativecommons.org/licenses/by/4.0/), which permits use, sharing, adaptation, distribution and reproduction in any medium or format, as long as you give appropriate credit to the original author(s) and the source, provide a link to the Creative Commons license and indicate if changes were made.

The images or other third party material in this chapter are included in the chapter's Creative Commons license, unless indicated otherwise in a credit line to the material. If material is not included in the chapter's Creative Commons license and your intended use is not permitted by statutory regulation or exceeds the permitted use, you will need to obtain permission directly from the copyright holder.

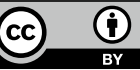

